\title{
Czy jest miejsce dla radioterapii w leczeniu kłykcin olbrzymich — przegląd piśmiennictwa
}

\author{
Grzegorz Woźniak, Grzegorz Głowacki, Leszek Miszczyk, Wioletta Miśta
}

Olbrzymie kłykciny kończyste zwane również guzem Buschke-Loewensteina powstają w wyniku zezłośliwienia kłykcin kończystych okolicy odbytu i narządów płciowych. Z uwagi na duże rozmiary i okolice zajęte, leczenie chirurgiczne, będące podstawową terapią, w wielu przypadkach jest niemożliwe do przeprowadzenia lub okaleczające. Rola radioterapii nie jest jednoznaczna. Autorzy przedstawiają dane z piśmiennictwa potwierdzające skuteczność leczenia kłykcin olbrzymich promieniami.

\section{Is there a place for radiotherapy in the management of giant condyloma: literature review}

Giant condyloma also known as Buschke-Loewenstein tumour, is a malignant tumour of the genital and anal area, arising from genital warts. Due to the large size and the infiltrated region, in many cases surgical treatment, which is essential, is impossible to perform without maiming the patient. The role of radiation therapy is not clear. The authors present a literature review of the efficacy of giant condyloma radiotherapy.

NOWOTWORY Journal of Oncology 2015; 65, 2: 128-131

Słowa kluczowe: kłykciny olbrzymie, guz Buschke-Loewensteina, radioterapia

Key words: giant condyloma, Buschke-Loewenstein tumour, radiotherapy

\section{Wstęp}

Kłykciny kończyste olbrzymie (Guz Buschke-Loewensteina) okolic odbytu i narządów płciowych nie są częstym schorzeniem, niemniej, wykazując naciekający wzrost, niszczą i deformują zajęte narządy. Chociaż podstawowym leczeniem tej choroby jest leczenie chirurgiczne, w wielu przypadkach jest niemożliwe do przeprowadzenia. Radioterapia, będąca w istocie leczeniem oszczędzającym, może dać szanse na trwałe wyleczenie i dobry efekt funkcjonalny.

\section{Charakterystyka guza}

Kłykciny olbrzymie (Guz Buschke-Loewensteina), opisane po raz pierwszy w 1925 r., powstają wskutek zezłośliwienia kłykcin kończystych [1]. Z uwagi na podobną histopatologię i przebieg kliniczny guz ten stanowi stadium przejściowe między kłykciami kończystymi a rakiem brodawkowatym, aczkolwiek zgodnie z klasyfikacją WHO zaliczane są one do nowotworów brzegu odbytu [2, 3]. Guz wykazuje miejscowy, ekspansywny wzrost, niszcząc głębsze tkanki, ale rzadko daje przerzuty do regionalnych węzłów chłonnych i przerzuty odległe, co zwykle wiąże się z transformacją do raka inwazyjnego. Jest to choroba dorosłych, choć opisano przypadek guza u 12-letniej dziewczynki [4]. Trzykrotnie częściej występuje u mężczyzn niż u kobiet, średnia wieku chorych to 44 lata [5]. W większości przypadków zmiany u mężczyzn dotyczą prącia (81-94\%), okolice odbytu są zajęte u 10-17\%. U kobiet zmiany najczęściej (w 90\%) dotyczą sromu [6].

Czynnikiem etiologicznym jest infekcja wirusem HPV typu 6 i 11, rzadziej 16 i 18, 54 [2]. Zakażenie wirusem HIV, zachowania homoseksualne, immunosupresja oraz choroby obniżające odporność, takie jak cukrzyca czy przewlekły

\section{Zakład Radioterapii}

Centrum Onkologii — Instytut im. Marii Skłodowskiej-Curie

Oddział w Gliwicach 
alkoholizm, są powszechnie uważane za czynniki ryzyka zachorowania [2, 7]. Badania wykazały, iż do zezłośliwienia łagodnych kłykcin kończystych dochodzi w 30-52\% przypadków, średnio w ciagu 5 lat $[8,9]$. Metcalf i wsp. sugerują, że malignizacji sprzyja homoseksualizm, immunosupresja i lokalizacja kłykcin powyżej linii grzebieniastej [10].

\section{Metody leczenia}

Zabieg operacyjny jest zasadniczym leczeniem kłykcin olbrzymich. Guzy tego typu stanowią jednak trudny problem chirurgiczny z uwagi na rozmiary i okolice zajęte. Ich wycięcie powoduje zwykle duże ubytki skórne i rany, które trudno się goją i powodują trwałe dysfunkcje odbytu. Co więcej, w 50\% przypadków dochodzi do nawrotów miejscowych [8].

Miejscowe leki: podofiline lub kwas dwu- lub trójchlorooctowy można zastosować w przypadku małych zmian, jednak leczenie takie w przypadku kłykcin olbrzymich ma niewielką skuteczność z uwagi na powierzchowne działanie leku. Również miejscowe leczenie chemioterapeutykiem (5-fluorouracyl) charakteryzuje się małą skutecznością [11].

Rola samodzielnej uzupełniającej chemioterapii nie jest jasna. Opisano pojedynczy przypadek wielolekowej adiuwantowej chemioterapii, jednak brak jest innych doniesień potwierdzających skuteczność takiego postępowania [12].

Obiecujące wyniki uzyskano, stosując immunoterapię z użyciem szczepionek lub interferonu [13, 14], nie jest to jednak terapia szeroko stosowana.

\section{Rola radioterapii}

Leczenie promieniami nie jest obecnie traktowane jako postępowanie rutynowe. Z uwagi na rzadkość schorzenia i słabo udokumentowaną rolę radioterapii w tej chorobie nie ma jednoznacznych wytycznych zarówno co do dawek radioterapii, jak i schematu i sekwencji leczenia. Co więcej, ze względu na możliwość transformacji anaplastycznej guza w raka inwazyjnego i powstanie przerzutów odległych niektórzy autorzy poddają w wątpliwość zastosowanie radioterapii $[15,16]$.

Radioterapię w przypadku kłykcin olbrzymich można rozważać w kilku przypadkach. Samodzielna radioterapia jest rzadko używana; jest ona zwykle stosowana jako leczenie pierwotne, gdy wycięcie guza nie jest możliwe lub w przypadku nawrotów. Radioterapia adiuwantowa może być rozważana jako uzupełnienie zabiegu w przypadku niekompletnego wycięcia $[17,18]$.

Zadowalające wyniki radiochemioterapii w leczeniu raka płaskonabłonkowego odbytu zarówno w zakresie wyleczeń miejscowych, jak i zachowania funkcji czynnościowych odbytu, zachęciły do zastosowania takiego leczenia w kłykcinach olbrzymich [19-21], niemniej brak jest wyraźnych wytycznych co do schematu i dawek.
Najczęściej spotykane schematy chemioterapii są analogiczne do używanych w leczeniu skojarzonym raka odbytu. Są to zwykle schematy dwulekowe 5-fluorouracyl (5FU) + mitomycyna C (MitC) lub 5-fluorouracyl + cisplatyna (DDP) [17, 18, 22, 23]. Autorzy podający wspomniane schematy chemioterapii nie odnotowali istotnych powikłań, jednak częste w tych guzach przetoki i szczeliny, powikłane ropniami i zlewną martwicą, przy immunosupresji w trakcie chemioterapii mogą byćźródłem powikłań septycznych. Stąd Tytherleigh i wsp. zastosowali zredukowaną dawkę leków z uwagi na ryzyko powikłań infekcyjnych [23]. Część autorów zaobserwowała także u pacjentów istotnego stopnia niedokrwistość [7, 11]. Obecność dużej masy nowotworu, powodując toksemię, działającą supresyjnie na hematopoezę, nasila niedokrwistość spowodowaną głównie krwawieniami z nacieku. Może to więc być kolejnym ograniczeniem do stosowania agresywnej chemioterapii Stopień anemizacji, rozległość nacieku nowotworowego, zły stan ogólny pacjenta i ryzyko powikłań bakteryjnych decydują często o rezygnacji ze schematu z mitomycyną Club cisplatyną i o podaniu mniej agresywnej chemioterapii w oparciu o 5Fu+ LV (leukovorin). Z drugiej strony całkowita rezygnacja z chemioterapii nie musi oznaczać gorszych efektów leczenia. Sobrado i wsp. stosowali samodzielną RT bez chemioterapeutyku, uzyskując wielomiesięczną całkowitą regresję [24].

Dawka całkowita i frakcyjna radioterapii nie jest również jednoznacznie ustalona. Najczęściej stosowana jest dawka 45 Gy $[22,24]$. Schemat leczenia podobny do leczenia raka odbytu w leczeniu kłykcin opisał Tytherleigh i wsp., którzy skojarzyli DDP i $5 F U$ z radioterapią podawaną w dwóch etapach. Zarówno dawki, jak i obszary były zdefiniowane podobnie jak w leczeniu raka odbytu [23]. W obu opisywanych przypadkach uzyskano regresję guza i zastosowano leczenia chirurgiczne jako ratunkowe na przetrwałe zmiany. W jednym przypadku doszło do kolejnej wznowy, i pacjent zmarł. Indinnimeo i wsp. zastosowali również podwyższenie dawki (boost) u 3 opisywanych pacjentów.W tym przypadku było stosowane leczenia dwuetapowe $z$ napromienianiem całej miednicy oraz chemioterapią ( $5 \mathrm{Fu}+\mathrm{mitC}$ ). Tolerancja leczenia była dobra, a w materiale pooperacyjnym po planowych wycięciach nie stwierdzano cech raka i kłykcin [18].

Biorąc jednak pod uwagę fakt niewielkiego ryzyka przerzutowania do węzłów chłonnych, dyskusyjna wydaje się kwestia dwuetapowego leczenia i konieczności radioterapii elektywnej regionalnych węzłów chłonnych. W przypadku braku cech inwazyjnego raka uzasadnione jest ograniczenie pola napromieniania do obszaru guza z marginesem i leczenie jednoetapowe szczególnie w przypadku dużego nacieku, którego pole leczenia obejmuje również spływ chłonny.

Hyacynte i wsp. zastosowali dawkę całkowitą 46,8 frakcjonowaną po 1,8 Gy w połączeniu z dwulekową chemioterapią (5Fu + mitC) jako leczenie przedoperacyjne, uzyskując 
całkowitą regresję guza w histopatologicznym badaniu pooperacyjnym [25]. Podobny schemat wcześniej zastosował Butler z takim samym efektem [26].

Część autorów stosowała pooperacyjne napromienianie. Bjorck opisał przypadek chorego leczonego pooperacyjną RT z ChT, z 4-letnim okresem obserwacji bez cech nawrotu [27], w przeciwieństwie do Chu i wsp., którzy przeanalizowali 42 przypadki z literatury i odnotowali chorego leczonego podobnie, u którego doszło do nawrotu po 8 miesiącach [8].

Dawka całkowita 45 Gy, spotykana najczęściej w literaturze, wydaje się niska jak na radykalną radioterapię raka płaskonabłonkowego z grupy brodawkowatych. Zwykle w przypadku raka inwazyjnego odbytu stosuje się dawki powyżej 50 Gy. Niemniej dane dotyczące wyników leczenia raka płaskonabłonkowego powstającego na tle infekcji wirusem HPV w innych lokalizacjach (np. w regionie głowy i szyi) wskazują, że te nowotwory są bardziej promieniowarażliwe i rokują lepiej [28]. W związku z tym zastosowane dawki poniżej 50 Gy wydają się wystarczające, tym bardziej, że zwykle napromienianie kojarzy się z chemioterapeutykami, które mają działanie promieniouczulające.

Nie ma jednoznacznych doniesień co do minimalnej skutecznej dawki całkowitej. Jedyna sugestia wynika z pracy Radovanovica i wsp., którzy opisali przypadek nawrotowego guza leczonego radiochemioterapią. Zastosowano tam dawkę $25 \mathrm{~Gy} / 5$ dfx wraz z 4 cyklami cisplatyny i 5Fu, a w efekcie leczenia doszło do progresji guza [17]. Sugeruje to, że dawka stosowana typowo jako przedoperacyjna w raku odbytnicy jest zbyt mała przy raku płaskonabłonkowym odbytu, nawet w skojarzeniu z chemioterapią.

W literaturze brak jest jednoznacznych danych co do postępowania chirurgicznego po radykalnej radiochemioterapii. W części cytowanych prac radioterapia była leczeniem neoadiuwantowym, po którym chorzy poddawani byli planowej operacji $[18,22,23,25,26]$. W innych przypadkach leczenie chirurgiczne było leczeniem ratunkowym po niewyleczeniu lub nawrocie [8, 23]. Również zakres zabiegu nie jest ostatecznie określony: częściej opisywano miejscowe wycięcie, natomiast brzuszno-kroczowe resekcje stosowano w bardziej zaawansowanych przypadkach.

\section{Podsumowanie}

Podsumowując dane z literatury można stwierdzić, że samodzielne leczenie chirurgiczne w przypadku zaawansowanych olbrzymich kłykcin kończystych nie daje zadowalających wyników. Podzielamy opinie części cytowanych autorów, że w takich przypadkach radiochemioterapia radykalna do dawki nie mniejszej niż 45 Gy z zastosowaniem wielolekowej chemioterapii (z mitomycyną $C$ lub cisplatyną) i z ewentualnym następowym miejscowym wycięciem zmian przetrwałych jest dobrą opcją leczenia, dającą choremu szansę na wielomiesięczny okres wolny od choroby i zadowalający efekt funkcjonalny. Rola radioterapii pozostaje więc dwojaka w zależności od efektu: jako terapia indukcyjna, umożliwiająca następowe leczenie operacyjne, lub w przypadku braku możliwości zabiegu chirurgicznego — jako samodzielne leczenie, również paliatywne.

\section{Konflikt interesów: nie zgłoszono}

\author{
Dr n. med. Grzegorz Woźniak \\ Zakład Radioterapii \\ Centrum Onkologii — Instytut im. Marii Skłodowskiej-Curie \\ Oddział w Gliwicach \\ ul. Wybrzeże AK 15, 44-100 Gliwice \\ e-mail:gwozniak@wp.eu
}

Otrzymano: 13 listopada 2014 r.

Przyjęto do druku: 18 stycznia 2015 r.

\section{Piśmiennictwo}

1. Buschke A, Loewenstein L. Uber carcinomahnliche condylomata acuminata des penis. Klin Wochenschr 1925; 4; 1726-1728.

2. Kołodziejczak M, Nasierowska-Guttmejer A, Sudoł-Szopińska I i wsp. Guz Buschke-Lowensteina - trudny problem interdyscyplinarny. Postępy Nauk Medycznych 2013; 8: 577-580

3. Asato, Y.Taira, K. Yamamoto Y i wsp. Detection of human papillomavirus type 11 in a case of Buschke-Löwenstein tumor. Eur J Dermatol 2008; 18: 329-331.

4. Ambriz-González G, Escobedo-Zavala LC, Carrillo de la Mora F i wsp. Buschke-Löwenstein tumor in childhood: a case report. J Pediatr Surg 2005; 40: e25-27.

5. Trombetta LJ, Place RJ. Giant condyloma acuminatum of the anorectum: trends in epidemiology and management: report of a case and review of the literature. Dis Colon Rectum 2001; 44: 1878-1886.

6. El Mejjad A, Dakir M, Tahiri M i wsp. Le condylome acuminé géant-tumeur de Buschke-Loewenstein (à propos de 3 cas). Prog Urol 2003; 13: 513-517.

7. Braga JC, Nadal SR, Stiepcich M i wsp. Buschke-Loewenstein tumor: identification of HPV type 6 and 11. An Bras Dermatol 2012; 87: 131-134.

8. Chu QD, Vezeridis MP, Libbey NP i wsp. Giant condyloma acuminatum (Buschke-Löwenstein tumor) of the anorectal and perianal regions. Analysis of 42 cases. Dis Colon Rectum 1994; 37: 950-957.

9. Creasman C, Haas PA, Fox TA Jr i wsp. Malignant transformation of anorectal giant condyloma acuminatum (Buschke-Löwenstein tumor). Dis Colon Rectum 1989; 32: 481-487.

10. Metcalf AM, Dean T. Risk of dysplasia in anal condyloma. Surgery 1995 118: 724-726.

11. Renzi A, Giordano P, Renzi G i wsp. Buschke-Lowenstein tumor successful treatment by surgical excision alone: a case report. Surg Innov 2006; 13:69-72.

12. Ilkay AK, Chodak GW, Vogelzang NJ i wsp. Buschke-Lowenstein tumor: therapeutic options including systemic chemotherapy. Urology 1993; 42: 599-602.

13. Wiltz $\mathrm{OH}$, Torregrosa $\mathrm{M}$, Wiltz $\mathrm{O}$. Autogenous vaccine: the best therapy for perianal condyloma acuminata? Dis Colon Rectum 1995; 38: 838-841.

14. Geusau A, Heinz-Peer G, Volc-Platzer B i wsp. Regression of deeply infiltrating giant condyloma (Buschke-Löwenstein tumor) following long-term intralesional interferon alfa therapy. Arch Dermatol 2000; 136: 707-710.

15. Fukunaga $\mathrm{M}$, Yokoi K, Miyazawa $\mathrm{Y}$ i wsp. Penile verrucous carcinoma with anaplastic transformation following radiotherapy. A case report with human papillomavirus typing and flow cytometric DNA studies. Am J Surg Pathol 1994; 18: 501-505.

16. Edström S, Johansson SL, Lindström J i wsp.Verrucous squamous cell carcinoma of the larynx: evidence for increased metastatic potential after irradiation. Otolaryngol Head Neck Surg 1987; 97: 381-384.

17. Radovanovic Z, Radovanovic D, Semnic R i wsp. Highly aggressive Buschke-löwenstein tumor of the perineal region with fatal outcome. Indian J Dermatol Venereol Leprol 2012; 78: 648-650.

18. Indinnimeo M, Impagnatiello A, D'Ettorre G i wsp. Buschke-Löwenstein tumor with squamous cell carcinoma treated with chemo-radiation therapy and local surgical excision: report of three cases. World J Surg Oncol 2013; 11: 231. 
19. Nigro ND, Vaitkevicius VK, Considine B Jr. Combined therapy for cancer of the anal canal: a preliminary report. Dis Colon Rectum 1974; 17: 354-356.

20. James RD, Glynne-Jones R, Meadows HM i wsp. Mitomycin or cisplatin chemoradiation with or without maintenance chemotherapy for treatment of squamous-cell carcinoma of the anus (ACT II): a randomised, phase 3, open-label, $2 \times 2$ factorial trial. Lancet Oncol 2013; 14: 516-524.

21. Cummings BJ, Keane TJ, O'Sullivan B i wsp. Epidermoid anal cancer: treatment by radiation alone or by radiation and 5 -fluorouracil with and without mitomycin C. Int J Radiat Oncol Biol Phys 1991; 21: 1115-1125.

22. Ahsaini $M$, Tahiri Y, Tazi MF i wsp. Verrucous carcinoma arising in an extended giant condyloma acuminatum (Buschke-Löwenstein tumor): a case report and review of the literature. J Med Case Rep 2013; 7: 273.

23. Tytherleigh MG, Birtle AJ, Cohen CE i wsp. Combined surgery and chemoradiation as a treatment for the Buschke-Löwenstein tumour. Surgeon 2006; 4: 378-383.
24. Sobrado CW, Mester M, Nadalin W i wsp. Radiation-induced total regression of a highly recurrent giant perianal condyloma: report of case. Dis Colon Rectum 2000; 43: 257-260.

25. Hyacinthe M, Karl R, Coppola D i wsp. Squamous-cell carcinoma of the pelvis in a giant condyloma acuminatum: use of neoadjuvant chemoradiation and surgical resection: report of a case. Dis Colon Rectum 1998; 41: 1450-1453.

26. Butler TW, Gefter J, Kleto D i wsp. Squamous-cell carcinoma of the anus in condyloma acuminatum. Successful treatment with preoperative chemotherapy and radiation. Dis Colon Rectum 1987; 30: 293-295.

27. Björck M, Athlin L, Lundskog B. Giant condyloma acuminatum (Buschke-Loewenstein tumour) of the anorectum with malignant transformation. Eur J Surg 1995; 161: 691-694.

28. Fakhry C, Westra WH, Li S i wsp. Improved survival of patients with human papillomavirus-positive head and neck squamous cell carcinoma in a prospective clinical trial. J Natl Cancer Inst 2008; 100: 261-269. 